\title{
In-House Validation of Rapid Detection PCRs for Bacterial Pathogens Causing Infant Diarrhea
}

\author{
Londero A ${ }^{1}$, Leotta GA ${ }^{1}$, Brusa V1', Costa $M^{1}$, Golijow $C^{1}$, Gutkind $\mathrm{G}^{2}$, Gonzalez $\mathrm{E}^{3}$ and Galli $\mathrm{L}^{\text {1* }}$ \\ ${ }^{1}$ Faculty of Veterinary Sciences, Institute of Veterinary Genetics (IGEVET), La Plata, Buenos Aires, Argentina \\ ${ }^{2}$ Faculty of Pharmacy and Biochemistry, Buenos Aires' University, Argentina
}

${ }^{3}$ Molecular Diagnostic Center, City of Buenos Aires, Argentina

\begin{abstract}
In Argentina, conventional culture methods for the isolation of diarrheal bacteria continue to be the most widely used form of diagnosis in many clinical laboratories. In this work we validated 11 in-house real-time polymerase chain reactions (PCRs) assays for the specific and rapid detection of Salmonella spp., Shigella spp., enteroinvasive E. coli, enteropathogenic E. coli, enterotoxigenic E. coli, Shiga toxin-producing E. coli, E. coli O157, Cronobacter sakazakii, Campylobacter jejuni, Campylobacter coli, Vibrio cholera and Clostridium difficile. The sensitivity of the assays was less than $10^{2} \mathrm{CFU} / \mathrm{ml}$ for all the studied pathogens; selectivity and specificity were $100 \%$ in all cases and robustness was optimal. These PCR methods could be used to accurately detect the main bacterial causes of infant gastroenteritis.
\end{abstract}

Keywords: RT-PCR; Validation; Infant; Diarrhea; Bacteria; Detection

\section{Introduction}

Worldwide, bacterial diarrhea causes high morbidity and mortality rates, particularly in developing countries. Diarrhea is associated with significant economic and social costs. In Argentina, although more than 300000 episodes of acute diarrhea were notified in the period 20142016 [1], disease underreporting is significant. The reasons for underregistration are varied, including some issues associated with laboratory diagnosis. Nowadays, conventional culture methods for isolating these bacteria are the most widely used form of diagnosis in many clinical laboratories of Argentina, even though their processing time precludes the design of patient therapy and control strategies in order to prevent dissemination. Therefore, the development of rapid techniques for the detection of pathogens causing diarrhoea is highly relevant. When dealing with qualitative analytical methods, the following performance parameters must be considered: sensitivity (limit of detection, LOD), selectivity/specificity (inclusivity/exclusivity) and robustness [2]. Although several polymerase chain reaction (PCR)-based methods to detect bacteria causing diarrhea has been developed elsewhere [3-5], none of the protocols have been validated with Argentinean indigenous and regional strains. The objective of this work was to validate 11 inhouse real time-PCRs for the rapid detection of 12 pathogenic bacteria that cause infant diarrhoea.

\section{In-House Validation of Rapid Detection for Bacterial Pathogens}

Primers and TaqMan probes previously described in the literature were tested for the detection of specific genes from Salmonella spp. (ttrRSBCA locus) [6], Shigella spp. and enteroinvasive E. coli (EIEC) (ipaH) [7], enteropathogenic E. coli (EPEC) (eae) [8], enterotoxigenic E. coli (ETEC) (eltA) [4], Shiga toxin-producing E. coli (STEC) (stx and $\left.s t x_{2}\right)$ [9], E. coli O157 ( $\left.r f b E_{\mathrm{O} 157}\right)$ [9], Cronobacter sakazakii (MMS operon) [10], Campylobacter jejuni/C. coli (cadF) [3], Vibrio cholerae (toxR) [4] and Clostridium difficile ( $t c d B)$ [4] by real-time PCR.

The following parameters were determined using pure bacterial cultures and for each target gene: a) working range (LOD), with one strain in cell suspensions ranging from $10^{1}$ to $10^{5}$ colony forming units $(\mathrm{CFU}) / \mathrm{ml}$; b) inclusivity, with ten positive strains (eight for C. sakazakii) at a concentration $10 \mathrm{X}$ above the LOD previously determined; c) exclusivity, with nine negative strains (the rest of the pathogens besides the target one) at a concentration of $10^{6} \mathrm{CFU} / \mathrm{ml}$; and d) robustness, with five positive and five negative strains at a concentration of $10^{6} \mathrm{CFU} / \mathrm{ml}$, changing the following variables: test day, equipment and laboratory place. The strains used to determine LOD, inclusivity, exclusivity and robustness are listed in Table 1. All strains excepting those from $C$. jejuni/C. coli, V. cholera, C. difficile; C. sakazakii and ETEC belong to the strain collection of IGEVET (Instituto de Genética Veterinaria "Ing. Fernando Noel Dulout", UNLP-CONICET LA PLATA), La Plata, Buenos Aires, Argentina. PCR standardization of C. jejuni/C. coli, V. cholerae and C. difficile was performed using quantified DNA from pure strains kindly provided by Virginia Zbrun, María Inés Caffer and José Di Conza, respectively.

DNA was extracted from bacterial cultures grown in brain heart infusion (Biokar, Zac de Ther, France) during the exponential growth phase. Bacterial concentration was then confirmed by plating on plate count agar (Britania, Argentina). The boiling protocol described by Leotta et al. [11] was used to perform all DNA extractions. Extracted DNA was then serially diluted in PCR-grade water to reach the desirable concentration.

Singleplex RT-PCRs were performed with a StepOne Plus thermocycler $(\mathrm{ABI})$ in a $25-\mu \mathrm{l}$ reaction mixture containing $12.5 \mu \mathrm{l}$ of PB-L master mix (Bio-Logical Products, Argentina), $0.4 \mu \mathrm{M}$ of each forward and reverse primer, $0.2 \mu \mathrm{M}$ of each 6-carboxyfluorescein (FAM)-labeled TaqMan probe (IDT, Biodynamics, Argentina) and $5 \mu \mathrm{L}$ of the template DNA, under the following conditions: initial denaturation at $95^{\circ} \mathrm{C}$ for $10 \mathrm{~min}$, and 40 two steps cycles of $95^{\circ} \mathrm{C}$ for 15

*Corresponding authors: Lucia Galli, Faculty of Veterinary Sciences Institute of Veterinary Genetics (IGEVET), La Plata, Buenos Aires, Argentina, Tel: 542214211799; E-mail: Igalli@igevet.gob.ar

Received December 18, 2017; Accepted December 26, 2017; Published December 29, 2017

Citation: Londero A, Leotta GA, Brusa V, Costa M, Golijow C, et al. (2017) InHouse Validation of Rapid Detection PCRs for Bacterial Pathogens Causing Infant Diarrhea. J Med Microb Diagn 6: 268. doi:10.4172/2161-0703.1000268

Copyright: $\odot 2017$ Londero A, et al. This is an open-access article distributed unde the terms of the Creative Commons Attribution License, which permits unrestricted use, distribution, and reproduction in any medium, provided the original author and source are credited. 
Citation: Londero A, Leotta GA, Brusa V, Costa M, Golijow C, et al. (2017) In-House Validation of Rapid Detection PCRs for Bacterial Pathogens Causing Infant Diarrhea. J Med Microb Diagn 6: 268. doi:10.4172/2161-0703.1000268

Page 2 of 3

\begin{tabular}{|c|c|c|c|c|c|}
\hline Bacteria & species/serotype & Source & $\mathbf{N}$ & Genotype & LOD \\
\hline \multirow{2}{*}{ Vibrio } & V. cholerae 01 & Human & 9 & toxR & * \\
\hline & V. cholerae no 01 no 0139 & Human & 1 & toxR & - \\
\hline \multirow{8}{*}{ Shigella } & S. boydii & ATCC349583 & 1 & ipaH & * \\
\hline & S. flexneri ser2 & Human & 1 & ipaH & - \\
\hline & S. flexneri & Human & 1 & ipaH & - \\
\hline & Shigella spp. & Human & 3 & ipaH & - \\
\hline & S. flexneri ser1 & Human & 1 & $i p a H$ & - \\
\hline & S. dysenteriae ser1 & Human & 1 & ipaH & - \\
\hline & S. sonnei & Human & 1 & ipaH & - \\
\hline & S. flexneri & ATCC12022 & 1 & ipaH & - \\
\hline ETEC & & Animal & 10 & eltA & * \\
\hline \multirow{7}{*}{ EPEC } & O157: H7 & Human & 4 & eae & * \\
\hline & O111: HNM & Human & 1 & eae & - \\
\hline & O145: HNM & Human & 1 & eae & - \\
\hline & O103: H25 & Human & 1 & eae & - \\
\hline & O157: H7 & Food & 1 & eae & - \\
\hline & O109: H25 & Food & 1 & eae & - \\
\hline & O103: H21 & Food & 1 & eae & - \\
\hline \multirow{14}{*}{ STEC } & O157:H7 & Human & 2 & stx2 /stx1 & * \\
\hline & O157:H7 & EDL933 & 1 & stx $2 / s t x 1$ & - \\
\hline & O145:HNM & Human & 1 & stx2 & - \\
\hline & $\mathrm{O}: \mathrm{H} 2$ & Human & 1 & $s t \times 2$ & - \\
\hline & O121:H19 & Human & 1 & $s t \times 2$ & - \\
\hline & O130:H21 & Food & 1 & $s t x 2 / s t x 1$ & - \\
\hline & O157:H7 & Food & 1 & stx2 /stx1 & - \\
\hline & O178:H19 & Food & 1 & $s t \times 2$ & - \\
\hline & O113:H21 & Human & 1 & $s t \times 2$ & - \\
\hline & O111:HNM & Human & 1 & $s t \times 1$ & - \\
\hline & O13:H16 & Animal & 1 & $s t \times 1$ & - \\
\hline & O128ab:H2 & Human & 1 & $s t \times 1$ & - \\
\hline & $\mathrm{O} 91: \mathrm{H} 21$ & Food & 1 & $s t \times 1$ & - \\
\hline & O103:H21 & Food & 1 & $s t \times 1$ & - \\
\hline \multirow{3}{*}{ O157 } & O157:H7 & Human & 7 & rfbEO157 & * \\
\hline & O157:H7 & EDL933 & 1 & rfbEO157 & - \\
\hline & O157:H7 & Food & 2 & $r f b E O 157$ & - \\
\hline \multirow{10}{*}{$\begin{array}{c}\text { Salmonella } \\
\text { enteritidis }\end{array}$} & Dublin & Animal & 1 & $t t r$ & - \\
\hline & Meleagridis & Food & 1 & $t t r$ & - \\
\hline & Derby & Food & 1 & $t t r$ & - \\
\hline & Senftenberg & Food & 1 & $t t r$ & - \\
\hline & Typhimurium & Animal & 1 & ttr & - \\
\hline & Mbandaka & Animal & 1 & ttr & - \\
\hline & Enteritidis & ATCC13076 & 1 & $t t r$ & - \\
\hline & Newport & Food & 1 & $t t r$ & - \\
\hline & Saintpaul & Food & 1 & ttr & - \\
\hline & Pullorum & ATCC13036 & 1 & $t t r$ & - \\
\hline \multirow{2}{*}{ Campylobacter } & C. jejuni & Animal & 5 & cadF & * \\
\hline & C. coli & Animal & 5 & cadF & - \\
\hline \multirow{2}{*}{ Clostridium } & C. difficile & ATCC43593 & 1 & $t c d B$ & * \\
\hline & C. difficile & Human & 9 & $t c d B$ & - \\
\hline \multirow{3}{*}{ Cronobacter } & C. sakazakii & Food & 6 & MMS & * \\
\hline & C. sakazakii & ATCC51329 & 1 & MMS & - \\
\hline & C. sakazakii & ATCC57329 & 1 & MMS & - \\
\hline
\end{tabular}

Table 1: Strains used to determine LOD, inclusivity, exclusivity and robustness.

$\mathrm{s}$ and $59^{\circ} \mathrm{C}$ for $1 \mathrm{~min}$. External positive (the one corresponding to each target gene) and negative (nuclease-free water) controls were included in each run. A fluorescent signal 10-fold higher than the standard deviation of the mean baseline emission was indicative of a positive detection. The cutoff values (threshold cycles) were set above the highest FAM end-point fluorescence signals of the negative samples.

The LOD was found to be less than $10^{2} \mathrm{CFU} / \mathrm{ml}$, depending on the pathogen. Inclusivity and exclusivity were $100 \%$ in all cases, and robustness was optimal when modifying the different variables mentioned previously (Table 2). 
Citation: Londero A, Leotta GA, Brusa V, Costa M, Golijow C, et al. (2017) In-House Validation of Rapid Detection PCRs for Bacterial Pathogens Causing Infant Diarrhea. J Med Microb Diagn 6: 268. doi:10.4172/2161-0703.1000268

Page 3 of 3

\begin{tabular}{|c|c|c|c|c|}
\hline Pathogen & Target gene & LOD $^{\mathrm{a}}(\mathrm{CFU} / \mathrm{ml})$ & Inclusivity \% & Exclusivity \% \\
\hline V. cholerae & toxR & $10^{1}$ & 100 & 100 \\
\hline C. jejuni/C. coli & cadF & $10^{1}$ & 100 & 100 \\
\hline Shigella spp./EIEC & $\mathrm{ipaH}$ & $10^{1}$ & 100 & 100 \\
\hline E. coli ${ }_{0157}$ & rfbEO157 & $10^{1}$ & 100 & 100 \\
\hline ETEC & eltA & $10^{1}$ & 100 & 100 \\
\hline EPEC & eae & $10^{1}$ & 100 & 100 \\
\hline STEC & stx1 & $10^{2}$ & 100 & 100 \\
\hline- & stx2 & $10^{2}$ & 100 & 100 \\
\hline Salmonella spp. & $t t r$ & $10^{2}$ & 100 & 100 \\
\hline C. difficile & $t c d B$ & $10^{2}$ & 100 & 100 \\
\hline C. sakazakii & MMS & $10^{1}$ & 100 & 100 \\
\hline
\end{tabular}

Table 2: RT-PCRs limit of detection, inclusivity and exclusivity.

\section{Discussion and Conclusion}

In conclusion, we achieve assays with $100 \%$ selectivity, no false positive results for any target, and high selectivity, accuracy and detection probability. The assays were robust against pipetting, equipment and temperature variability.

The LOD of our assays $\left(10^{1}\right.$ to $\left.10^{2} \mathrm{CFU} / \mathrm{ml}\right)$ was below the analytical sensitivity of other reported RT-PCR-based methods $[3,4,6,10]$ and the bacterial burden often reported in symptomatic patients, as measured by culture methods ( $10^{3}$ to $10^{9} \mathrm{CFU} / \mathrm{g}$ stool for bacteria). Despite preliminary assays showed consistent results applying the RT-PCRs with DNA extracted from stool specimens, a validation assay in this kind of matrix is required.

We believe that 11 different simplex real-time PCR assays represent an easier and more reliable strategy (simultaneous detection and PCR product verification) than conventional multiplex PCR (limitations in the ability to resolve many fragments in agarose and potential nonspecific products generation). It is important to point out that all the target genes/microorganisms were standardized with the same master mix quantities and cycling conditions so that clinical applications of the PCR assay panel described here will offer a substantially shorter turnaround time compared with other described PCRs and conventional cultures, and if adopted may contribute to improve diarrhea diagnosis, patient management, dissemination control and epidemiological surveillance.

\section{Acknowledgements}

This work was supported by BID FITS-FONARSEC 003. We thank Fabiana Moredo, Virginia Zbrun, Sergio Epszteyn, María Inés Caffer and José Di Conza for kindly providing DNA/strains not belonging to IGEVET. We also thank A. Di Maggio for editing the manuscript.

\section{References}

1. Salud M (2016) Boletín Integrado de Vigilancia No.309-SE19. Mayo de Disponible en: consultado.

2. Feldsine P, Abeyta C, Andrews WH (2002) AOAC International methods committee guidelines for validation of qualitative and quantitative food microbiological official methods of analysis. J AOAC Internat 85: 1187-1200.

3. Cunningham SA, Sloan LM, Nyre LM, Vetter EA, Mandrekar J, et al. (2010) Three-hour molecular detection of Campylobacter, Salmonella, Yersinia, and Shigella species in feces with accuracy as high as that of culture. J Clin Microbiol 48: 2929-2933.

4. Liu J, Gratz J, Amour C, Kibiki G, Becker S, et al. (2013) A laboratory-developed TaqMan Array Card for simultaneous detection of 19 enteropathogens. J Clin Microbiol 51: 472-480.

5. O'Leary J, Corcoran D, Lucey B (2009) Comparison of the EntericBio multiplex PCR system with routine culture for detection of bacterial enteric pathogens. Clin Microbiol 47: 3449-3453.

6. Malorny B, Paccassoni E, Fach P, Bunge C, Martin A, et al. (2004) Diagnostic real-time PCR for detection of Salmonella in food. Appl Environ Microbiol 70: 7046-7052.

7. Wang SM, Ma JC, Hao ZY, Zhang ZY, Mason C, et al. (2010) Surveillance of shigellosis by real-time PCR suggests underestimation of shigellosis prevalence by culture-based methods in a population of rural China. J Infect 61: 471-475.

8. Nielsen EM, Andersen MT (2003) Detection and characterization of verocytotoxin-producing $E$. coli by automated 5' nuclease PCR assay. J Clin Microbiol 41: 2884-2893

9. Perelle S, Dilasser F, Grout J, Fach P (2004) Detection by 5'-nuclease PCR of Shiga-toxin producing E. coli O26, 055, 091, 0103, 0111, 0113, 0145 and 0157:H7, associated with the world's most frequent clinical cases. Mol Cell Probes 18: 185-192.

10. Seo KH, Brackett RE (2005) Rapid, specific detection of Enterobacter sakazakii in infant formula using a real-time PCR assay. J Food Prot 68: 59-63.

11. Leotta GA, Chinen I, Epszteyn S, Miliwebsky E, Melamed IC, et al. (2005) Validación de una técnica Rev argent microbiol 37: 1-10. 